\title{
Antibacterial effectiveness in vitro of different formulations of calcium hy- droxide paste
}

\author{
Eficácia antibacteriana in vitro de diferentes formulações de pastas de hidróxido de cálcio
}

Israel Alexandre De Araujo SENA ${ }^{1}$

Isaac Jordão De Souza ARAÚJO²

Marquiony Marques Dos SANTOS 3

Isabela Pinheiro Cavalcanti LIMA ${ }^{4}$

\section{ABSTRACT}

\section{Objective}

To evaluate the antibacterial activity of four formulations of calcium hydroxide paste against microorganisms commonly found in infected root canals.

\section{Methods}

To evaluate antibacterial activity through the agar diffusion method, pastes of calcium hydroxide were made from its pro-analysis form, diffused

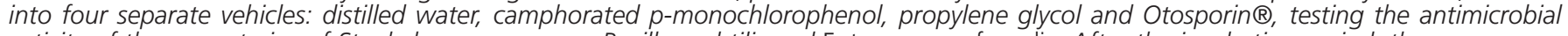
activity of these on strains of Staphylococcus aureus, Bacillus subtilis and Enterococcus faecalis. After the incubation period, the presence or otherwise of inhibition zones were observed and their sizes in three stages: $24 \mathrm{~h}, 48 \mathrm{~h}$ and $72 \mathrm{~h}$. With this data, the median between the four dishes was obtained and the consequent value was submitted to Kruskal-Wallis nonparametric statistical analysis, with post-tests of MannWhitney and Bonferroni correction, at a significance level of $5 \%$.

\section{Results}

Only pastes with camphorated p-monochlorophenol and Otosporin vehicles caused the formation of significant inhibition zones, with medians of $8.0 \mathrm{~mm}$. Against the strains of Enterococcus faecalis, only pastes with the camphorated p-monochlorophenol vehicle resulted in the formation of significant inhibition zones, with a median of $3.0 \mathrm{~mm}$.

\section{Conclusion}

Otosporin and CMCP vehicles provide greater antimicrobial potential to calcium hydroxide against the studied bacteria. However, only the $\mathrm{Ca}(\mathrm{OH})_{2}$ and $C M C P$ combination was effective against all the strains, and can thus be regarded as the paste formulation with the greatest antimicrobial effectiveness in this study.

Indexing terms: Calcium hydroxide. Dental pulp cavity. Dentistry.

\section{RESUMO}

\section{Objetivo}

Avaliar a ação antibacteriana de quatro formulações de pastas de hidróxido de cálcio contra microrganismos comumente encontrados em canais radiculares infectados.

\section{Métodos}

Para avaliar a ação antibacteriana, através do método de difusão em ágar, foram preparadas pastas de hidróxido de cálcio a partir de sua forma pró-análise dispersa em quatro veículos distintos: água destilada, paramonoclorofenol canforado, propilenoglicol e Otosporin ${ }$, testando o potencial antibacteriano destas sobre cepas de Staphylococcus aureus, Bacillus subtilis e Enterococcus faecalis. Após o período de incubação, foi verificada a pre $\neg$ sença ou não de halos de inibição e seus respectivos tamanhos em três momentos: $24 \mathrm{~h}, 48 \mathrm{~h}$ e $72 \mathrm{~h}$. Com os dados, foi

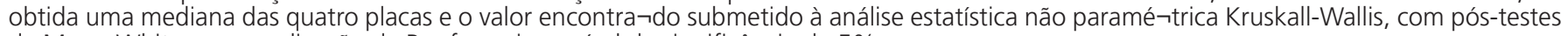
de Mann-Whitney e penalização de Bonferroni, ao nível de significância de $5 \%$.

\section{Resultados}

Apenas nas pastas com veículos paramonoclorofenol canforado e Otosporin foi observado a formação de halos de inibição significativos, com medianas de $8,0 \mathrm{~mm}$. Sobre as cepas de Enterococcus faecalis, somente a pasta com veículo paramonoclorofenol canforado foi observado formação de halo de inibição significativo, com mediana de $3,0 \mathrm{~mm}$.

\section{Conclusão}

Os veículos Otosporin e PMCC possibilitam maior potencial antimicrobiano ao hidróxido de cálcio frente às bactérias estudadas. No entanto, somente a associação $\mathrm{Ca}(\mathrm{OH})_{2}$ e PMCC foi efetiva contra todas as cepas, e assim pode ser considerada como a formulação de pasta de maior efetividade antimicrobiana neste estudo.

Termos de indexação: Cavidade pulpar. Hidróxido de cálcio. Odontologia.

\footnotetext{
${ }^{1}$ Universidade Federal do Rio Grande do Norte, Programa de Pós-graduação em Saúde Coletiva. Av. Sen. Salgado Filho, 3000, Lagoa Nova, 59078-970, Natal, RN, Brasil. Correspondência para / Correspondence to: IAA SENA. E-mail: <israelodonto.ias@gmail.com>.

${ }^{2}$ Universidade Estadual de Campinas, Faculdade de Odontologia, Programa de Pós-graduação em Materiais Dentários. Piracicaba, SP, Brasil.

${ }^{3}$ Universidade Federal do Rio Grande do Norte, Programa de Pós-graduação em Ciências da Saúde. Natal, RN, Brasil.

${ }^{4}$ Universidade do Estado do Rio Grande do Norte, Curso de Odontologia. Caicó, RN, Brasil.
} 


\section{INTRODUCTION}

The main aims of endodontic treatment are the elimination of microorganisms and the prevention of reinfection inside the root canal. Due to the complex anatomy of the root canal system and the ability of microorganisms to survive in adverse conditions, resistant microorganisms may remain inside the root canals even after full mechanical endodontic instrumentation and irrigation procedures ${ }^{1}$.

In view of the insufficiency of these procedures in combating all microorganisms present in the infected root canal $^{2}$, as well as the possibility of bacterial infiltration from temporary restorations, between sessions of endodontic treatment ${ }^{3}$, intracanal medication has been used as an auxiliary resource in endodontic treatment ${ }^{2}$.

In this regard, several substances have been advocated, with calcium hydroxide $\left(\mathrm{Ca}(\mathrm{OH})_{2}\right)$ being considered the primary clinical choice ${ }^{4}$. This is due to its antibacterial properties, solvent action on organic materials, inducement to form mineralized tissue ${ }^{5}$, alkalizing effect, control of the inflammatory and replacement resorption of the root $^{1}$, neutralization effect in bacterial lipopolysaccharides (LPS) ${ }^{6}$ and, lastly, antifungal action ${ }^{7}$.

It has been well established that endodontic infections are polymicrobial in nature ${ }^{8}$. For some of the bacteria involved in these infections, mainly Enterococcus faecalis ${ }^{9}$, whose resistance in highly alkaline $\mathrm{pH}$ is well established ${ }^{10}$, the effectiveness of calcium hydroxide needs to be enhanced. This can be achieved through the use of particular vehicles in the formulation of calcium hydroxide pastes, which should be capable of improving diffusion through the canals and increasing the antibacterial effect ${ }^{11}$.

In view of this, $\mathrm{Ca}(\mathrm{OH})_{2}$ powder has been combined with different vehicles, such as distilled water (DW), saline solution, camphorated p-monochlorophenol (CMCP), chlorhexidine, polyethylene glycol, propylene glycol (PG), Otosporin (O), glycerine ${ }^{12}$, and also with chlorhexidine ge ${ }^{13-14}$, in an attempt to improve its antibacterial activity, biocompatibility, speed of ion dissociation and diffusion ${ }^{11}$.

Many studies have compared the effectiveness of calcium hydroxide pastes and the use of various vehicles in several respects, namely: the inhibitory behavior towards bacterial infiltration via the crown ${ }^{15}$; the relationship of each vehicle with the potential for the diffusion of the calcium hydroxide paste into the dentin tubules ${ }^{16}$; and the degradation of these pastes over the course of time ${ }^{17}$ that results in a greater or lesser degree of substantivity and effectiveness against endodontic pathogens.

Considering the differences between the types of vehicles used in the formulation of calcium hydroxide pastes, in terms of nature, viscosity, miscibility, differences in the characteristics of these pastes are observed when in contact with the root canal structure. These differences may represent alterations in $\mathrm{pH}$, ion dispersion and even alterations in antimicrobial capacity ${ }^{9}$.

Due to the changes in the antimicrobial potential of some formulations of calcium hydroxide paste against particular bacteria found inside the root canals, the aim of this study was to perform a comparative evaluation of the antibacterial action of four different formulations of calcium hydroxide paste, used as intracanal medication in dentistry, against microorganisms that have been detected in infected root canals.

\section{METHODS}

The methodology for this study was adapted from Ganesh et al. ${ }^{18}$, who used the agar diffusion test to determine the antibacterial effectiveness of calcium hydroxide pastes on the strains of bacteria commonly found in infected root canals.

An analysis of the antibacterial action of the tested substances was conducted using the method of agar diffusion in a Brain Heart Infusion (BHI) (DIFCO ${ }^{\circledR}$, Maryland, USA) culture medium. Pastes were prepared by mixing pro-analysis calcium hydroxide (Inodon Laboratório Industrial de Produtos Odontológicos Ltda., Porto Alegre, Rio Grande do Sul, Brazil) combined with a water-soluble vehicle, distilled water; with an oily vehicle, camphorated p-monochlorophenol (Biodinâmica, Ibiporã, Paraná, Brazil); a viscous vehicle, propylene glycol (Farmafómula ${ }^{\circledR}$ - Farmácia de Manipulação, Caicó, Rio Grande do Norte, Brazil) and Otosporin ${ }^{\circledR}$ (hydrocortisone, neomycin and polymixin B, FQM - Farmoquímica, Rio de Janeiro, RJ, Brazil).

The antibacterial action of the proposed pastes was tested on standard strains obtained from the American Type Culture Collection (ATCC): Staphylococcus aureus ATCC 25923, Bacillus subtilis ATCC 6051 and Enterococcus faecalis ATCC 29212.

The standard strains were initially diluted in 10 $\mathrm{ml}$ of distilled water with the help of a sterile platinum strap and test tube together with a Bunsen burner until a turbidity that was visually comparable with standard 0.5 on the McFarland scale was obtained. The strains were 
then cultivated separately inside the dishes, in which there was $35 \mathrm{ml}$ of $\mathrm{BHI}$ culture medium, to a dish depth of $4 \mathrm{~mm}$.

Each of the three strain types was inoculated with the aid of a sterile swab on four dishes containing $\mathrm{BHI}$ agar. With the aim of avoiding the formation of isolated colonies, the inoculation was performed in horizontal, vertical and diagonal directions. Following this procedure, on each of the dishes, four depressions were made (diameter of $7 \mathrm{~mm}$ and depth of $4 \mathrm{~mm}$ ) together with the culture medium with the aid of a pre-sterilized glass tube.

Each depression was then uniformly filled with one of the four substances tested, in other words, the four different formulations of calcium hydroxide-based paste were analyzed on the same dish. For each substance, four tests were carried out with each of the cultivated microorganisms.

The tested pastes were handled at the point of use using a sterile glass dish and no. 24 stainless steel spatula. It is worth stressing that all substances were handled with standardized quantities of calcium hydroxide powder (100 $\mathrm{mg})$ and the volume of each vehicle $(0.15 \mathrm{ml})$, such that a paste with a consistency of toothpaste was obtained after mixing, using a precision scale and pipette for the standardization of these values.

With the aid of an insertion spatula, the pastes were placed in each of the wells in quantities sufficient to fill them. After a two-hour wait for the diffusion of the calcium hydroxide paste in the medium to occur, the dishes were kept in an oven for 24 hours at $37^{\circ} \mathrm{C}$.

Following this incubation, a check was made of the presence or absence of an inhibition halo with the different paste formulations analyzed, and also the size at three different points in time: 24, 48 and 72 hours. The size of the halo was checked in a horizontal direction, the inhibition zone being considered as the distance, in millimeters, between the edges of the diffusion halo formed by the calcium hydroxide paste and the edge of the inhibition halo arising from the inhibition of bacterial growth caused by the pastes. To perform the measurements, a plastic millimeter ruler was employed.

With the data obtained from the measurement of the inhibition halos, the median value of the four dishes was obtained and the consequent value was then submitted to statistical analysis using the Kruskal-Wallis non-parametric test and Mann-Whitney and Bonferroni correction post-tests, at a level of significance of $5 \%$. The tests were conducted using the software application SPSS $^{\circledR} 20.0$.

\section{RESULTS}

The median values for the inhibition halos, in the different formulations of calcium hydroxide paste, in the samples of the following bacteria: Staphylococcus aureus ATCC 25923, Bacillus subtilis ATCC 6051 and Ente $\neg$ rococcus faecalis ATCC 29212 at the different times of analysis, are described in Table 1.

Table 1. Comparison of the median (in millimeters) of the inhibition halo of the different formulations of calcium hydroxide paste in samples of the bacteria Staphylococcus aureus ATCC 25923, Enteᄀrococcus faecalis ATCC 29212 and Bacillus subtilis ATCC 6051, Caicó (RN), 2015.

\begin{tabular}{|c|c|c|c|c|c|c|c|c|c|}
\hline \multicolumn{4}{|c|}{ ATCC 25923} & \multicolumn{3}{|c|}{ ATCC 29212} & \multicolumn{3}{|c|}{ ATCC 6051} \\
\hline Sample & Median & Q25-Q75 & $p^{*}$ & Median & Q2-Q75 & $p^{*}$ & Median & Q25-Q75 & $p^{*}$ \\
\hline $\mathrm{Ca}(\mathrm{OH}) 2+\mathrm{DW}$ & $0.00 a$ & $0.00-0.00$ & 0.020 & $0.00 a$ & $0.00-0.00$ & 0.012 & $0.00 a$ & $0.00-0.00$ & 0.016 \\
\hline $\mathrm{Ca}(\mathrm{OH}) 2+\mathrm{O}$ & $8.00 \mathrm{~b}$ & $7.50-8.00$ & & $0.00 a$ & $0.00-0.00$ & & $6.00 b$ & $6.00-6.50$ & \\
\hline $\mathrm{Ca}(\mathrm{OH}) 2+\mathrm{PG}$ & $0.00 a$ & $0.00-0.00$ & & $0.00 a$ & $0.00-0.00$ & & $0.00 a$ & $0.00-0.00$ & \\
\hline
\end{tabular}

Note: * Kruskal-Wallis test. a, b: Mann-Whitney with Bonferroni correction post-tests.

At the second and third moments of analysis, at 48 and 72 hours respectively, it was observed that there was no significant difference in the sizes of the inhibition halos versus the first analysis performed at 24 hours.

A statistically significant difference was observed between the substances evaluated with regard to antibacterial action against the bacteria Staphylococcus aureus ATCC 25923 and Bacillus subtilis ATCC $6051(p<0.05)$. Of the four substances analyzed, only the calcium hydroxide paste with distilled water and the paste with propylene glycol had not formed an inhibition halo at any of the moments of analysis nor on any of the strains used in this study, whereas the pastes with the vehicles CMCP and Otosporin led to the formation of significant inhibition halos.

The individual susceptibility of microorganisms to calcium hydroxide pastes varied, with Staphylococcus 
aureus ATCC 25923 being the most susceptible and Enterococcus faecalis ATCC 29212 the most resistant. Only with the calcium hydroxide paste that used CMCP as a vehicle was it possible to see the formation of a significant inhibition halo in the samples with Enterococcus faecalis ATCC 29212 at the different times of analysis.

All of the calcium hydroxide-based paste formulations exhibited diffusion halos, on which there was no bacterial growth, remaining so for the three different moments of analysis.

\section{DISCUSSION}

The antibacterial action of the intracanal medications must reach the different types of microorganisms that infect the root canal and also inhibit osteoclastic activity and promote tissue repair. Several substances have been recommended to this end with $\mathrm{Ca}(\mathrm{OH})_{2}$ being the intracanal medication most frequently employed ${ }^{19}$.

The action of calcium hydroxide is directly influenced by the release of calcium $\left(\mathrm{Ca}^{2+}\right)$ and hydroxyl $\left(\mathrm{OH}^{-}\right)$ions, responsible for the alkalinization of the medium and resulting in a $\mathrm{pH}$ above 11 . Moreover, this is capable of inactivating the enzymes of the cytoplasmic membrane of the organisms, which chemically alters the organic components and transportation of nutrients, causing toxic effects on the cells ${ }^{6,20}$. Another action mechanism of this medication is its ability to absorb carbon dioxide $\left(\mathrm{CO}_{2}\right)$, thereby leading to the death of $\mathrm{CO}_{2}$-dependent bacteria ${ }^{3}$.

Various methods areused to evaluate the antibacterial activity of intracanal medications, the in vitro method having the advantage of ease of execution and speed of results, as well as being free of certain factors that influence them, which are inherent to in vivo studies². Of the in vitro preparations, the most common method for evaluating antimicrobial activity is the agar diffusion method $^{8}$.

On the other hand, the results of agar diffusion tests have to be carefully examined when using materials such as $\mathrm{Ca}(\mathrm{OH})_{2}$, because the culture medium possesses buffering substances and, even though the calcium hydroxide does diffuse, the magnitude of the $\mathrm{pH}$ achieved around the medication may not be sufficient to exert antibacterial activity ${ }^{21}$. Nevertheless, it is important to mention that, a similar effect could be produced by the tissue fluids and dentin in ex-vivo or in vivo conditions ${ }^{1}$.

Given the low solubility of $\mathrm{Ca}(\mathrm{OH})_{2}$, its inability to diffuse adequately and the fact that it requires aT long period of time to alkalinize the culture medium ${ }^{19}$, it was decided to keep the dishes at room temperature for 2 hours to allow the diffusion of the medications through the agar, and only afterwards to be incubated under the appropriate conditions.

Due to the difficulty of using calcium hydroxide powder in small or curved canals, it has been used in combination with a liquid vehicle in order to facilitate clinical handling during application ${ }^{8,22}$. Moreover, this combination has the objective of improving antibacterial activity and biocompatibility as well as influencing the paste's $\mathrm{pH}$ and viscosity and, therefore, facilitating or inhibiting its ion dispersion ${ }^{11,23}$.

A number of studies have asserted that the combination of calcium hydroxide with distilled water permits a rapid, efficient dissociation and that paste with propylene glycol has greater viscosity and antimicrobial potential ${ }^{16}$. However, in the present study, pastes that used these substances as a vehicle were unable to produce an inhibition halo in any of the tested strains, corroborating the study by Pacíos et al. ${ }^{19}$.

The ineffectiveness of calcium hydroxide mixed with these vehicles in vitro may, as already mentioned, also be related, as per Gomes et al. ${ }^{24}$, to the fact that the culture medium possesses buffering substances and to the vehicle's low diffusion capacity. Therefore, although calcium hydroxide may have diffused through the medium, the $\mathrm{pH}$ levels attained were not sufficient to present inhibitory activity.

Calcium hydroxide paste with Otosporin exhibited antibacterial activity against Staphylococcus aureus ATCC 25923 and Bacillus subtilis ATCC 6051. In concert with our study, Estrela et al. ${ }^{20}$ demonstrated the antibacterial potential of the combination of $\mathrm{Ca}(\mathrm{OH})_{2}$ and Otosporin on these bacteria via the broth dilution method. Moreover, the literature stresses that the combination of calcium hydroxide and corticosteroids (such as the hydrocortisone present in Otosporin) could act as an enhancer in the reduction of pain and inflammation ${ }^{25}$.

Of all the formulations of calcium hydroxide-based pastes used in this study, only the one using camphorated p-monochlorophenol as the vehicle promoted the formation of inhibition halos against all bacterial strains, thus demonstrating it is the most effective, consistent with other studies in the literature ${ }^{8,18}$

Nevertheless, the size of the bacterial inhibition zone may be influenced by the molecular size of the chemical substance, toxicity against the tested bacteria and 
diffusion. An agent that diffuses more easily will exhibit a larger zone and it has been demonstrated that CMCP diffuses more easily through the agar medium ${ }^{18}$.

Enterococcus faecalis has been linked to persistent endodontic infections, having differential characteristics such as the ability to penetrate into the dentin tubules, growing in an alkaline $\mathrm{pH}$, coping with inanition and resisting the action of antibiotics ${ }^{3,26-27}$. So, of the pastes tested in our study, only calcium hydroxide paste with the CMCP vehicle was capable of promoting the formation of a significant inhibition halo in the samples with Enterococcus faecalis ATCC 29212, as per the study by Gomes et al. ${ }^{24}$.

Despite the low solubility of calcium hydroxide in water thus limiting its diffusibility ${ }^{21}$, in our study, the presence of diffusion halos in agar was observed for all paste formulations. Accordingly, it may be assumed that these are capable of killing bacteria through direct contact, which means that the remaining microorganisms in contact with this medication will be eradicated if they are not resistant.

Moreover, as this is an in vitro study, the results must be analyzed with caveats before extrapolating to clinical conditions. Accordingly, the use should also be considered of other research methods, such as in vivo studies, for a better understanding of the antimicrobial action of these calcium hydroxide-based intracanal medications.

Similarly, other analyses, using the same methodology but longer time intervals, may be insightful in the sense of relating the time vs. drug effectiveness curve, which will certainly have largescale clinical implications as a result of the various indications regarding the length of time the intracanal drugs should be applied.

\section{REFERENCES}

1. Turk B, Sen B, Ozturk T. In vitro antimicrobial activity of calcium hydroxide mixed with different vehicles against Enterococcus faecalis and Candida albicans. Oral Surg Oral Med Oral Pathol Oral Radiol Endod. 2009;108(2):297-301. doi: 10.1016/j. tripleo.2009.03.029

2. Maia Filho E, Maia C, Bastos A, Novais T. Efeito antimicrobiano in vitro de diferentes medicações endodônticas e própolis sobre Enterococcus faecalis. RGO, Rev Gaúch Odontol. 2008;56(1):21-5.

3. Silveira C, Cunha R, Fontana C, Martin A, Gomes B, Motta R, et al. Assessment of the antibacterial activity of calcium hydroxide combined with chlorhexidine paste and other intracanal medications against bacterial pathogens. Eur J Dent. 2011;5 (1):1-7.

\section{CONCLUSION}

Thus, it could be seen from the results of our study that the vehicles Otosporin and CMCP enhance the antimicrobial potential, for the bacteria studied, of calcium hydroxide. Nevertheless, only the combination of $\mathrm{Ca}(\mathrm{OH})_{2}$ with CMCP was effective against all of the strains studied, and thus may be considered as the paste formulation with greatest antimicrobial efficacy given the in vitro study method employed and the substances and strains used.

\section{Collaborators}

IAA SENA was responsible for designing, drawing, drafting the manuscript and approval of this final version. IJS ARAÚJO was responsible for drafting the manuscript and approval of this final version. MM SANTOS was responsible for the design, drawing, analysis and interpretation of the manuscript data. IPC LIMA was responsible for designing and drawing, data analysis and interpretation, writing, reviewing and approving its final version of the manuscript.

\section{ACKNOWLEDGMENTS}

Our sincere thanks go to the National Council for Scientific and Technological Development (CNPq) for the financial backing for this study, under case reference no. 125219/2014-8, and to the State University of Rio Grande do Norte for allowing us the use of its premises at the Microbiology Laboratory at the Caicó campus.

4. Kim D, Kim E. Antimicrobial effect of calcium hydroxide as an intracanal medicament in root canal treatment: a literature review - Part I. In vitro studies. Restor Dent Endod. 2014; 39(4):241-52. doi: 10.5395/rde.2015.40.2.97

5. Garcia LF, Almeida GL, Pires-de-Souza FCP, Consani S. Antimicrobial activity of a calcium hydroxide and Ricinus communis oil paste against microorganisms commonly found in endodontic infections. Rev Odonto Ciênc. 2009;24(4):406-9.

6. Vianna ME, Zilio DM, Ferraz CCR, Zaia AA, Souza-Filho FJ, Gomes BPFA. Concentration of hydrogen ions in several calcium hydroxide pastes over different periods of time. Braz Dent J. 2009;20(5): 382-388 doi: 10.1590/S010364402009000500005

7. Blanscet ML, Tordik PA, Goodell GG. An agar diffusion comparison of the antimicrobial effect calcium hydroxide at five different concentrations with three different vehicles. J Endod. 2008;34(10):1246-8. doi: 10.1016/j.joen.2008.07.012 
8. Gangwar A. Antimicrobial effectiveness of different preparations of calcium hydroxide. Indian J Dent Res. 2011;22(1):66-70. doi: 10.4103/0970-9290.79986

9. Mohammadi Z, Dummer PMH. Properties and applications of calcium hydroxide in endodontics and dental traumatology. Int Endod J. 2011;44(8):697-730. doi: 10.1111/j.13652591.2011.01886.x

10. McHugh $C P$, Zhang $P$, Michalek S, Eleazer PD. pH Required to Kill Enterococcus faecalis in vitro. J Endod. 2004;30(4):218-9. doi: 10.1097/00004770-200404000-00008

11. Farhad AR, Barekatain B, Allameh M, Narimani T. Evaluation of the antibacterial effect of calcium hydroxide in combination with three different vehicles: an in vitro study. Dent Res J. 2012;9(2):167-72. doi: 10.4103/1735-3327.95231

12. Estrela C, Decurcio DA, Alencar AHG, Sydney GB, Silva JA. Efficacy of calcium hydroxide dressing in endodontic infection treatment: a systematic review. Rev Odonto Ciênc. 2008;23(1):82-6.

13. Önçag O, Gogulu D, Uzel A. Efficacy of various intracanal medicaments against Enterococcus faecalis in primary teeth: An in vivo study. J Clin Pediatr Dent. 2006;30(3):233-8. doi: 10.17796/jcpd.30.3.r773j6l674lw0268

14. Gondim JO, Moreira Neto JJS, Gomes DAS, Azevedo ER, Jeremias F, Giro EMA. In vivo study of an intracanal dressing of calcium hydroxide/chlorhexidine in necrotic primary teeth. Braz J Oral Sci. 2014;13(1):70-5. doi: 10.1590/1677-3225v13n1a14

15. Murad C, Fariniuk LF, Fidel S, Fidel RAS, Sassone LM. Bacterial leakage in root canals filled with calcium hydroxide paste associated with different vehicles. Braz Dent J. 2008;19(3):2327. doi: 10.1590/S0103-64402008000300011

16. Mori GG, Ferreira FC, Batista FRS, Godoy AMS, Nunes DC. Evaluation of the diffusion capacity of calcium hydroxide pastes through the dentinal tubules. Braz Oral Res. 2009;23(2):113-8. doi: 10.1590/S1806-83242009000200004

17. Gupta S. An in vitro study of diffusibility and degradation of three calcium hydroxide pastes. Int J Clin Pediatr Dent. 2011;4(1):15-23. doi: 10.5005/jp-journals-10005-1075

18. Ganesh MR, Chaurasia VR, Masamatti VKS, Mujeeb A, Jhamb A, Agarwal JH. In vitro evaluation of antibacterial efficacy of calcium hydroxide in different vehicles. J Int Soc Prev Community Dent. 2014;4(1):56-60. doi: 10.4103/2231-0762.131268

19. Pacíos MG, Silva C, López ME, Cecilia M. In Antibacterial action of calcium hydroxide vehicles and calcium hydroxide pastes. J Investig Clin Dent. 2012;3(4):264-70. doi: 10.1111/j.20411626.2012.00147.x
20. Estrela C, Bammann LL, Pimenta FC, Pécora JD. Control of microorganisms in vitro by calcium hydroxide pastes. Int Endod J. 2001;34:341-5. doi: 10.1046/j.1365-2591.2001.00368.x

21. Dotto SR, Travassos RMC, Ferreira R, Santos R, Wagner $M$. Avaliação da ação antimicrobiana de diferentes medicações usadas em endodontia. Rev Odonto Ciênc. 2006;21(53):266-9.

22. Estrela C, Pécora JD, Souza-Neto MD, Estrela CRA, Bammann LL. Effect of vehicle on antimicrobial properties of calcium hydroxide pastes. Braz Dent J. 1999;10(2):63-72.

23. Vianna ME, Gomes BPFA, Sena NT, Zaia AA, Ferraz CCR, SouzaFilho FJ. In vitro evaluation of the susceptibility of endodontic pathogens to calcium hydroxide combined with different vehicles. Braz Dent J. 2005;16(3):175-80. doi: 10.1590/S010364402005000300001

24. Gomes BP, Ferraz CC, Garrido FD, Rosalen PL, Zaia AA, Teixeira FB, et al. Microbial susceptibility to calcium hydroxide pastes and their vehicles. J Endod. 2002;28(11):758-61. doi: 10.1097/00004770-200211000-00003

25. Tabrizizadeh M, Rasti M, Ayatollahi F, Mossadegh MH, Zandi $\mathrm{H}$, Dehghan $\mathrm{F}$, et al. Antimicrobial activity of calcium hydroxide and Betamethasone on Enterococcus faecalis: An in vitro Assessment. Iran Endod J. 2015;10(3):184-7. doi: 10.7508/ iej.2015.03.008

26. Saha S, Nair R, Asrani H. Comparative evaluation of propolis, metronidazole with chlorhexidine, calcium hydroxide and curcuma longa extract as intracanal medicament against e.faecalis: an in vitro study. J Clin Diagn Res. 2015;9(11): doi: 10.7860/jcdr/2015/14093.6734

27. Valera MC, Oliveira SAC, Maekawa LE, Cardoso FGR, Chung A, Silva SFP, et al. Action of chlorhexidine, zingber officinale, and calcium hydroxide on candida albicans, enterococcus faecalis, escherichia coli, and endotoxin in the root canals. J Contemp Dent Pract. 2016;17(2):114-8. doi: 10.5005/jpjournal-10024-1812 